\title{
Leprosy incidence, characterization of cases and correlation with household and cases variables of the Brazilian states in 2010*
}

\author{
Shamyr Sulyvan de Castro ${ }^{1}$ \\ Graziela Basílio Abreu ${ }^{1}$ \\ Luciane Fernanda Rodrigues Martinho Fernandes ${ }^{1}$
}

\author{
Juliana Pereira Pontes Santos ${ }^{1}$ \\ Vanessa Rossato Oliveira ${ }^{1}$
}

DOI: http://dx.doi.org/10.1590/abd1806-4841.20164360

\begin{abstract}
BACKGROUND: Leprosy is millenary disease and still persists in several countries.
OвJестіVEs: To estimate the incidence of leprosy in the Brazilian states and for the country in the year 2010; to describe the cases reported according to the studied variables; to verify the correlation between the overall incidence and the studied variables.

Methods: Ecological descriptive study, with population data from the 27 states, 2010. Information about reported cases were collected: gender, race, percentage of patients younger than 15 years old and living conditions. The analysis was performed using percentages, means, incidence rates and the Spearman correlation test.

Results: The states of Mato Grosso and Tocantins recorded the highest incidence rates; Rio Grande do Sul and Santa Catarina, the lowest; there was a higher incidence of leprosy among men; the incidence of leprosy increases proportionally with the nonwhites among the inhabitants; patients younger than 15 years; the average number of residents per household; and a decrease in coverage of water supply and presence of bathrooms.

CONCLUSION: The incidence of leprosy is related to factors as gender, race and house conditions ( $\mathrm{p}<0,05$ for all).
\end{abstract}

Keywords: Health policy; Incidence; Leprosy

\section{INTRODUCTION}

Leprosy is an infectious disease, with chronic evolution, and symptoms of skin lesions associated with decreased thermal, painful and tactile sensitivity, due to the predilection of Mycobacterium leprae in affecting skin and peripheral nerve cells. The peripheral nervous system involvement results, in addition to the loss of sensation, in atrophy, paresis and muscle paralysis that may progress to permanent physical disabilities. ${ }^{1}$ The disease is a serious public health problem in Brazil, also presenting socio-economic aggravation, with psychological repercussions caused by the physical consequences of the disease, contributing to decreased self-esteem and self-segregation of patients with diagnosis of leprosy. In addition, the disease has a strong stigmatizing social impact among the affected people, who formely were isolated and treated with discrimination and segregation. ${ }^{2}$

Elimination of leprosy has been the subject of discussion due to its long social history and to the inefficiency of its actions, both in Brazil and around the world. ${ }^{3}$ The member countries of the World Health Organization (WHO), among them Brazil, have committed themselves in 1991 to promote the use of all control measures for the elimination of leprosy as a public health problem by the year 2000, but Brazil still failed to meet this goal. In August 2011 the Ministry of Health defined a set of endemic diseases that require strategic actions for elimination as a public health problem or

Approved by the Advisory Board and accepted for publication on 09.03.2015.

Study performed at Universidade Federal do Triângulo Mineiro (UFTM) - Uberaba (MG), Brazil.

Financial Support: None.

Conflict of Interest: None.

Universidade Federal do Triângulo Mineiro (UFTM) - Uberaba (MG), Brazil.

(C2016 by Anais Brasileiros de Dermatologia 
for drastically reducing the burden of some diseases, and leprosy is one of them. This integrated action plan for the period 2011-2015 is characterized by prioritizing the strategy of active search of cases and timely provision of treatment in vulnerable populations identified in geographic areas of higher risk and by proposing intersectoral action in the government context. ${ }^{4}$ Thus, Brazil plans to eliminate leprosy by 2015.

For these actions to have positive effects, it is necessary the previous study of risk groups and populations susceptible to leprosy by providing subsidies for understanding the persistence of this disease in the population and thus set goals for its elimination. Given that the new plan of action of Ministry of Healht started in 2011, an analysis of incidence coefficients of leprosy in different Brazilian states and in the country, as well as its relation with social factors, in 2010, will be the basis for evaluation of this new plan, considering that the measures adopted so far have not achieved the expected results.

Thus the objectives of this study are to estimate the leprosy incidence rate for Brazilian states and for the country in 2010, to characterize the reported cases by gender, race, percentage of individuals $<15$ years and social factors and, lastly, to correlate total incidence coefficient with the variables of the characterization.

\section{METHODS}

This research is a descriptive, ecological study, with population data from the 27 states of the federation, in 2010. The basis for the population survey was the Brazilian Institute of Geography and Statistics (IBGE) website.

Initially we calculated the leprosy incidence rate for Brazilian states and for the country, in 2010, through the following equation, and the process was conducted for the total population and according the gender.

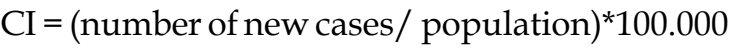

Later it was collected information on cases reported that year, according to the variables: race, percentages of patients $<15$ years and living conditions (water supply, presence of bathroom in the house and mean number of residents per household) selected due to its availability in the IBGE database.

Information on self-reported cases of leprosy and age and race data were extracted from the Notifiable Diseases Information System (SINAN), in 2010.

The correlation of leprosy incidence rates was analyzed with the following variables: percentage of nonwhites, percentages of patients $<15$ years, mean of residents per household, water supply and presence of bathroom in the house.
The descriptive analysis was performed using percentages, means and leprosy incidence rates in 2010. For the inferential analysis, the Spearman correlation test between the total incidence rate and the other variables was performed, respecting the non-parametric distribution data, tested by the Shapiro-Wilk test. The significance level adopted was 5\%.

\section{RESULTS}

The highest incidence rates were found in the states of Mato Grosso and Tocantins, with 103.25/100,000 and 94.83/100,000, respectively, when compared with other states. In contrast, Rio Grande do Sul and Santa Catarina presented the lowest coefficients, with $1.64 / 100,000$ and $3.79 / 100,000$, respectively.

Regarding the characterization, there was a higher prevalence of leprosy among men for all states. The highest percentage of individuals $<15$ diagnosed with leprosy was found in Acre (11.43\%) and the lowest in Santa Catarina $(0.84 \%)$. Nonwhite patients were the most affected in most states, except in the states of Santa Catarina and Rio Grande do Sul, where the percentage of nonwhite population is much lower compared with other states. For social factors, the mean of residents per household ranged from 3.0 to 4.3. The lowest percentage of houses with water supply was found in the state of Rondônia (38.5\%) and in Piauí only $80.08 \%$ of houses had bathrooms (Table 1 ).

Significant correlation coefficients between the incidence of leprosy in the population and the variables were found: percentage of individuals $<15$ with leprosy, percentage of nonwhites, higher mean number of residents per household, fewer houses with water supply and the presence of bathroom in the house (Table 2). We observed that the highest coefficients are located in the states with the highest percentage of diagnosis of leprosy in individuals $<15$ years and inasmuch as the percentage of nonwhite increases. Regarding the conditions of the household, the higher the mean number of residents per household, the greater were the incidence rates in the states. The lowest coefficients were related to a higher number of households with water supply and higher number of bathrooms.

\section{DISCUSSION}

For 14 years Brazil has proposed to eliminate leprosy as a public health problem, however the data presented in this study, performed in 2010, reveal that the measures adopted still did not have the expected effect. The incidence of reported cases of leprosy in the states is heterogeneous, and the highest are found in the North, Northeast and Midwest regions. The percentage of cases in individuals $<15$ years is still high in 
TABLE 1: Distribution of incidence rates, age and race of patients, mean residents per household, presence of bathrooms in the house and water supply according to state in the country, 2010

\begin{tabular}{|c|c|c|c|c|c|c|c|c|}
\hline \multirow[t]{2}{*}{ State } & \multicolumn{3}{|c|}{ Incidence/100.000 } & \multirow{2}{*}{$\begin{array}{l}\text { Individuals } \\
<15 \text { years }(\%)\end{array}$} & \multirow{2}{*}{$\begin{array}{l}\text { Patients } \\
\text { Nonwhite (\%) }\end{array}$} & \multirow{2}{*}{$\begin{array}{l}\text { Mean of } \\
\text { residents } \\
\text { per household }\end{array}$} & \multirow{2}{*}{$\begin{array}{l}\text { Households } \\
\text { with } \\
\text { Water } \\
\text { supply (\%) }\end{array}$} & \multirow{2}{*}{$\begin{array}{l}\text { Households } \\
\text { wit } \\
\text { Bathroom (\%) }\end{array}$} \\
\hline & Male & Female & Total & & & & & \\
\hline Rondônia & 75.079510 & 61.518250 & 68.419980 & 4.75 & 65.33 & 3.4 & 38.50 & 98.41 \\
\hline Acre & 44.797520 & 28.748610 & 36.806860 & 11.43 & 90.40 & 3.8 & 47.27 & 91.20 \\
\hline Amazonas & 32.740520 & 16.581870 & 24.713080 & 7.10 & 89.00 & 4.3 & 64.56 & 94.94 \\
\hline Roraima & 52.870980 & 19.402580 & 36.405690 & 8.80 & 73.58 & 3.9 & 81.23 & 94.28 \\
\hline Para & 74.048160 & 47.749340 & 61.007370 & 9.98 & 85.62 & 4.1 & 47.94 & 95.81 \\
\hline Amapá & 35.508080 & 15.251610 & 25.391100 & 9.57 & 91.48 & 4.2 & 54.54 & 97.96 \\
\hline Tocantins & 111.044000 & 78.118000 & 94.835720 & 5.78 & 82.63 & 3.5 & 78.64 & 92.05 \\
\hline Maranhão & 87.566670 & 62.204330 & 74.785670 & 9.59 & 82.53 & 4.0 & 65.88 & 86.21 \\
\hline Piauí & 61.370490 & 52.895140 & 57.049220 & 7.36 & 86.09 & 3.7 & 72.22 & 80.08 \\
\hline Ceara & 33.858500 & 25.506120 & 29.577460 & 5.33 & 82.88 & 3.6 & 77.22 & 92.76 \\
\hline Rio Grande do Norte & 10.459120 & 9.078894 & 9.753705 & 2.90 & 69.67 & 3.5 & 86.38 & 98.06 \\
\hline Paraíba & 21.267510 & 18.587660 & 19.885690 & 5.88 & 71.12 & 3.5 & 76.71 & 94.47 \\
\hline Pernambuco & 38.173520 & 36.226110 & 37.162730 & 8.97 & 81.52 & 3.4 & 76.02 & 95.12 \\
\hline Alagoas & 15.544720 & 14.607820 & 15.061720 & 5.09 & 80.89 & 3.7 & 68.62 & 93.64 \\
\hline Sergipe & 25.869590 & 20.884760 & 23.307350 & 6.58 & 81.68 & 3.5 & 83.54 & 96.98 \\
\hline Bahia & 24.744610 & 21.824890 & 23.257630 & 6.35 & 83.59 & 3.4 & 80.34 & 92.08 \\
\hline Minas Gerais & 10.900370 & 7.322620 & 9.082870 & 3.16 & 63.61 & 3.2 & 86.28 & 98.74 \\
\hline Espírito Santo & 34.599920 & 28.928080 & 31.721630 & 7.59 & 64.96 & 3.2 & 83.84 & 99.58 \\
\hline Rio de Janeiro & 14.542970 & 12.266490 & 13.352150 & 6.17 & 59.37 & 3.0 & 84.57 & 99.87 \\
\hline São Paulo & 6.454867 & 4.432522 & 5.416580 & 3.08 & 37.89 & 3.2 & 95.05 & 99.92 \\
\hline Paraná & 15.006840 & 9.485216 & 12.197780 & 1.80 & 27.96 & 3.2 & 88.06 & 99.63 \\
\hline Santa Catarina & 4.128553 & 3.462432 & 3.792949 & 0.84 & 14.40 & 3.1 & 81.48 & 99.71 \\
\hline Rio Grande do Sul & 1.844360 & 1.457494 & 1.647334 & 2.27 & 17.04 & 3.0 & 85.33 & 99.34 \\
\hline Mato Grosso do Sul & 38.854750 & 27.743970 & 33.278560 & 3.68 & 56.80 & 3.2 & 82.87 & 99.64 \\
\hline Mato Grosso & 119.197000 & 86.632480 & 103.257800 & 5.34 & 65.88 & 3.3 & 74.61 & 98.62 \\
\hline Goiás & 57.921400 & 41.436820 & 49.485420 & 4.66 & 66.58 & 3.2 & 79.31 & 99.39 \\
\hline Distrito Federal & 11.392490 & 8.201121 & 9.727021 & 3.03 & 75.45 & 3.3 & 95.11 & 99.91 \\
\hline Brasil & 25.666170 & 18.853850 & 22.189630 & 6.53 & 72.50 & 3.3 & 82.85 & 97.36 \\
\hline
\end{tabular}

TABLE 2: Correlation coefficients between leprosy incidence rates and the variables studied, 2010

\begin{tabular}{lll}
\hline Variables & Correlation coefficients & Significance \\
\hline Percentage of nonwhites & 0.47 & $0.0113^{*}$ \\
Percentage of individuals $<15$ years & 0.61 & $0.0006^{*}$ \\
Mean of residentes per household & 0.46 & $0.0148^{*}$ \\
Water supply & -0.69 & $0.0001^{*}$ \\
Presence of bathroom in the household & -0.52 & $0.0052^{*}$ \\
\hline
\end{tabular}

some states, highlighting the deficiency in surveillance and disease control. This study also found a relation between the deficient sanitary conditions and a higher incidence of the disease. As this survey was conducted in 2010, just before introducing the integrated strategic plan of action proposed by the Ministry of Health to eliminate leprosy and other diseases, started in 2011, we suggest that its findings could be used as comparative parameters as one of the verification forms of the plan impacts.

\section{Leprosy incidence in the Brazilian states}

The incidence of reported cases of leprosy in the country in the year 2010 was $22.18 / 100,000$, value higher than that found in Africa (5.92/100,000); South Asia $(12.17 / 100,000)$; Democratic Republic of Congo $(18.7 / 100,000)$; and Tanzania $(11.1 / 100,000)$ in $2005 .^{5}$

In all states there was a prevalence of leprosy among men compared with women, as reported by literature. ${ }^{6}$ In Brazil, the incidence rate of the disease in men was $25.66 / 100,000$ and for women was 
18.85/100,000. Differences between the occurrence of the disease between genders could be explained by cultural and sociological characteristics of the disease. ${ }^{7}$

The high coefficients in the states of Tocantins and Mato Grosso, demonstrated in this research, draws the attention. These rates are consistent with that preented in the literature, also being reported high detection rates, which would be indicators of disease endemicity. ${ }^{8,9}$ In addition, the leprosy detection rate is linked to the Brazilian Amazon occupation mode, biome related to the two states mentioned. ${ }^{10}$

This information show different needs among Brazilian states regarding the fight against leprosy. According to the plan of strategic actions for eliminating leprosy and other endemic diseases of the Ministry of Health, municipalities with priority for surveillance are located in all Brazilian states, but are concentrated mainly in the states of Maranhão, Mato Grosso, Pará and Rondônia. ${ }^{4}$ Based on this information, it is expected to direct efforts to assist more intensively the states with the highest incidence rates. To change this situation the new plan proposes the training of SUS professionals in diagnosis and treatment actions as well as health education, with emphasis on self-care, for the systematic and continuous care of patients in the healthcare primary network. ${ }^{4}$ Also, the population of these states could be subject of more intense campaigns about the disease, its detection and treatment. Actions in these three spheres - health services, health professionals and population - could decrease the impact of the disease in the population, thereby reducing its occurrence.

\section{Individuals $<\mathbf{1 5}$ years with leprosy}

The coefficient of annual incidence of leprosy in individuals $<15$ years has been used as an important endemic disease control indicator in the country, this occurs because there would be a relation between the time of infection and the degree of disability generated by the disease, which, in this population, would be synonymous of high degree of disability at diagnosis. ${ }^{11,12}$ Our study found a percentage above $8 \%$ of patients $<15$ years in the states of Acre, Pará, Maranhão, Amapá, Pernambuco and Roraima. In the state of Acre this percentage was $11.43 \%$, much higher than Brazil's percentage of $6.53 \%$. Similar values have been reported in the literature in leprosy case studies in individuals $<15$ years in the Vale do Jequitinhonha, region in the state of Minas Gerais, and found this population in $7.8 \%$ of the total cases detected from 1998 to $2006 .{ }^{13}$

Health services have adopted several measures in the fight against leprosy in this population, however, in some places, the actions do not seem to have had the necessary effect. ${ }^{13}$ In addition, the detection rate of leprosy in individuals $<15$ years can mean per- sistence in transmitting the bacillus and difficulties of health programs for disease control. ${ }^{14}$ The association between the incidence of leprosy cases among individuals $<15$ years and the highest incidence of the disease in the total population suggests that areas with the highest number of cases also present the highest incidence of disease among individuals $<15$ years.

This information justifies the adoption of more specific prevention and control measures aimed at this population, such as active surveillance in daycare, schools and among the communicators, reducing the risk of contracting the disease. The integrated plan of action of the Ministry of Health aims to reduce by $26.9 \%$ the detection rate of new cases of leprosy in individuals $<15$ years by 2015 and therefore it proposes a collaboration with the School Health Program (PSE) to conducting educational actions focusing on signs and symptoms of the disease, active case search in students and their household contacts. ${ }^{4}$

\section{Race}

Social factors are directly related to the occurrence of leprosy in the population groups, including, race, ethnicity or skin color. ${ }^{15}$ In this study, we found a direct correlation between the percentage of nonwhites and the occurrence of leprosy. This information reinforces the associative nature of the disease to social inequities. This association is evident, with indication that the fight against leprosy is incorporated into poverty reduction programs. ${ }^{16}$ The findings of this study and the data presented in the literature demonstrate the connection of leprosy with the social determinants of health, showing that the disease does not originate only in the disease process, but also and mainly on the social factors that influence directly the health of some population groups. ${ }^{17}$ Furthermore, it is possible to see that people in worse social conditions, including the "nonwhite", are exposed to a greater possibility of contact with leprosy, representing a group that should be target of particular attention in prevention campaigns and leprosy control.

\section{Residents per household}

The number of residents per household is often related to worse health conditions. ${ }^{18}$ The literature suggests that the number of people per household may be related to satisfaction with the health system, food expenditures, drugs consumption and children health. ${ }^{19-22}$ It is also an important variable when studying leprosy because it is associated with the contamination through direct contact with patients. Thus, control and monitoring of people living in the same household as the sick individuals with leprosy is of utmost importance, being determinant in the infectious process in the population. This need is already report- 
ed in the literature and ratified by the federal government, through the Ministry of Health, which issued the Ordinance 3125, of October 7th, 2010, addressing guidelines for surveillance, care and control of leprosy and, in addition, provided more financial resources by Decree 3097 of December 16, 2013, highlighting the importance of leprosy in the population and for the health system. ${ }^{23-29}$

\section{Water supply and sanitary facilities}

The inverse association between water supply and the presence of leprosy has been reported in the literature in 1994 in the metropolitan region of Rio de Janeiro; this relationship also has its roots in social and environmental inequalities, determinants of various diseases in the country. ${ }^{30}$ However, the persistence of this leprosy distribution pattern in the country reflects a possible inefficiency in combating and preventing the disease, as 18 years have passed and this association is still present. Considering this, a reflection on the social and health policies has to be made, regarding their effectiveness, efficiency and efficacy. Other information that demonstrates the relation of leprosy with social variables is its inverse correlation with the presence of bathrooms in households. The absence of bathrooms or sanitary facilities is seen in households of poor or socially vulnerable people. Such evidence reinforces once again that, in Brazil, leprosy has a deep relation with the social situation of the population, highlighting the need not only for investments in health, but also in the socio-economic field for the effective fight against the disease. This action is configured as one of the challenges in disease elimination process because it does not involve only changes in health conditions, but also in its social determinants. However, actions related to improvement of health conditions of the municipalities are not proposed in the integrated strategic plan of action of the Ministry of Health.
The reduced number of variables addressed by this study can be considered a limitation of the survey. Longitudinal population-based studies could be more efficient in determining the correlations found here. It should also be mentioned that the population structure varies widely across the studies in the country, which can interfere in the results. Leprosy and health of people with leprosy are issues widely explored in the scientific literature, nevertheless the problems persist, justifying the need to maintain the discussion in academic and social levels. In addition to bringing a much discussed and yet unresolved issue, the study adds large amount of data, with representation for the whole country, which is configured as another strong point, considering that studies of this size are not common.

This study was conducted in the year prior to the integrated plan of strategic actions proposed by the Ministry of Health to eliminate leprosy and other diseases. We believe that this study will serve as a parameter for assessing the results after the implementation of the actions proposed in this plan.

\section{CONCLUSION}

For 14 years Brazil has proposed to eliminate leprosy as a public health problem, however the data presented in this study, performed in 2010, reveals that the measures adopted still did not have the expected effect. The incidence of reported cases of leprosy in Brazil states is heterogeneous, with the highest incidence rates in the states of Mato Grosso and Tocantins. Nonwhite men were the most affected by leprosy. The percentage of cases in individuals $<15$ years is still high in some states, highlighting the deficiency in surveillance and disease control. This study also found significant correlations regarding the increased incidence of the disease and deficient social conditions.] 


\section{REFERENCES}

1. Eidt LM. Breve história da hanseníase: sua expansão do mundo para as Américas, 0 Brasil e 0 Rio Grande do Sul e sua trajetória na saúde pública brasileira. Saúde e Sociedade. 2004;13:76-88.

2. Monteiro YN. Violência e profilaxia: os preventórios paulistas para filhos de portadores de hanseníase. Saúde e Sociedade. 1998;7:3-26.

3. Talhari S, Penna G. Reflexões sobre a Política Global de Controle de Hanseníase. Rev Soc Bras Med Trop. 2005;38:362-364.

4. Brasil. Ministério da Saúde. Plano integrado de ações estratégicas de eliminação da hanseníase, filariose, esquistossomose e oncocercose como problema de saúde pública, tracoma como causa de cegueira e controle das geohelmintíases : plano de ação 2011-2015. Brasília : Ministério da Saúde; 2012. 100 p. (Série C. Projetos, Programas e Relatórios).

5. World Helath Organization. Global leprosy situation. Weekly Epidemiological Record. 2006;81:309-316.

6. Miranzi SSC, Pereira LHM, Nunes AA. Perfil epidemiológico da hanseníase em um município brasileiro, no período de 2000 a 2006. Rev Soc Bras Med Trop. 2010;43:62-7.

7. Irgens LM, Skjaerven R. Secular trends in age at onset, sex ratio, and type index in leprosy observed during declining incidence rates. Am J Epidemiol. 1985;122:695-705.

8. Magalhães MCC,Rojas LI. Diferenciação territorial da hanseníase no Brasil. Epidemiol Serv Saúde. 2007;16:75-84.

9. Silva Sobrinho RA, Mathias TAF. Perspectivas de eliminação da hanseníase como problema de saúde pública no Estado do Paraná, Brasil. Cad Saúde Pública. 2008;24:303-314.

10. Silva DRX, Ignotti E, Souza-Santos R, Hacon SS. Hanseníase, condições sociais e desmatamento na Amazônia brasileira. Rev Panam Salud Publica. 2010;27:268-75.

11. Sousa MW, Silva DC, Carneiro LR, Almino ML, Costa AL. Epidemiological Profile of Leprosy in the Brazilian state of Piauí between 2003 and 2008. An Bras Dermatol. 2012;87:389-95.

12. Alencar CHM, Barbosa JC, Ramos Jr AN, Alencar MJF, Pontes RJS, Castro CGJ, et al. Hanseníase no município de Fortaleza, CE, Brasil: aspectos epidemiológicos e operacionais em menores de 15 anos (1995-2006). Rev Bras Enferm. 2008;61:694-700.

13. Lana FCF, Amaral EP, Lanza FM, Lima PL, Carvalho ACN, Diniz LG. Hanseníase em menores de 15 anos no Vale do Jequitinhonha, Minas Gerais, Brasil. Rev Bras Enferm. 2007;60:696-700.

14. Pires CAA, Malcher CMSR, Abreu Júnior JMC, Albuquerque TG, Corrêa IRS, Daxbacher ELR. Hanseníase em menores de 15 anos: a importância do exame de contato. Rev Paul Pediatr. 2012;30:292-5.

15. Santos AS, Castro DS, Falqueto A. Fatores de risco para transmissão da Hanseníase. Rev Bras Enferm. 2008;61:738-43.

16. Lockwood DN. Commentary: Leprosy and poverty. Int J Epidemiol. 2004;33:26970.

17. Dssbr.org [Internet]. Lamarca G, Vettore M. Hanseníase: sua origem reside nas desigualdades sociais não atendidas? [acesso 20 Mar 2014]. Disponível em: http://dssbr.org/site/2012/06/hanseniase-sua-origem-reside-nas-desigualdadessociais-nao-atendidas/

18. Pimentel PG, Sichieri R, Salles-Costa R. Insegurança alimentar, condições socioeconômicas e indicadores antropométricos em crianças da Região Metropolitana do Rio de Janeiro/Brasi. Rev Bras Estud Popul. 2009;26:283-94.

19. Gouveia GC, Souza WV, Luna CF, Souza-Júnior PRB, Szwarcwald CL. Satisfação dos usuários do sistema de saúde brasileiro: fatores associados e diferenças regionais. Rev Bras Epidemiol. 2009;12:281-96.

20. Bezerra IN, Sichieri R. Características e gastos com alimentação fora do domicílio no Brasil. Rev Saúde Pública. 2010;44:221-9.

21. Arrais PSD, Brito LL, Barreto ML, Coelho HLL. Prevalência e fatores determinantes do consumo de medicamentos no Município de Fortaleza, Ceará, Brasil. Cad Saúde Pública. 2005;21:1737-46.

22. Cesar JA, Gonçalves TS, Neumann NA, Oliveira Filho JA, Diziekaniak AC. Saúde infantil em áreas pobres das regiões Norte e Nordeste do Brasil: comparando indicadores básicos em áreas atendidas pela Pastoral da Criança e áreas-controle. Cad Saúde Pública. 2005;21:1845-55.

23. Martins ACC, Miranda A, Oliveira MLWR, Bührer-Sékula S, Martinez A. Estudo da mucosa nasal de contatos de hanseníase, com positividade para 0 antígeno glicolipídio fenólico 1. Braz J Otorhinolaryngol. 2010;76:579-87.
24. Martelli CMT, Stefani MMA, Penna GO, Andrade ALSS. Endemias e epidemias brasileiras, desafios e perspectivas de investigação científica: hanseníase. Rev Bras Epidemiol. 2002;5:273-285.

25. Peixoto BKS, Figueiredo IA, Caldas AJM, Correa RGCF, Aquino DMC. Aspectos epidemiológicos dos contatos de hanseníase no município de São Luís-Ma. Hansen Int. 2011; 36:23-30.

26. Vieira CSCA, Soares MT, Ribeiro CTSX, Silva LFG. Avaliação e controle de contatos faltosos de doentes com hanseníase. Rev Bras Enferm. 2008;61:682-8.

27. Pereira AJ, Helene LMF, Pedrazini ES, Martins CL, Vieira CSCA. Atenção básica de saúde e a assistência em Hanseníase em serviços de saúde de um município do Estado de São Paulo. Rev Bras Enferm. 2008;61:716-25.

28. Brasil. Ministério da Saúde. Portaria n. 3.125, de 7 de outubro de 2010. Aprova as Diretrizes para Vigilância, Atenção e Controle da Hanseníase. Diário Oficial da União 15 out 2010.

29. Brasil. Ministério da Saúde. Portaria n. 3.097, de 16 de dezembro de 2013 Autoriza o repasse financeiro do Fundo Nacional de Saúde aos Fundos de Saúde dos Municípios com alta carga da doença para implantação, implementação de ações contingenciais de vigilância, prevenção e controle da hanseníase e esquistossomose, como problemas de saúde pública. Diário Oficial da União 17 dez 2013.

30. Aquino DMC, Caldas AJM, Silva AAM, Costa JML. Perfil dos pacientes com hanseníase em área hiperendêmica da Amazônia do Maranhão, Brasil. Rev Soc Bras Med Trop. 2003;36:57-64.

\author{
MAILING ADDRESS: \\ Shamyr Sulyvan de Castro \\ Av. Frei Paulino, 30 \\ Bairro Abadia \\ 38025-180 - Uberaba - MG \\ Brazil \\ Email: shamyrsulyvan@gmail.com
}

How to cite this article: Castro SS, Santos JPP, Abreu GB, Oliveira VR, Fernandes LFRM. Leprosy incidence, characterization of cases and correlation with household and cases variables of the Brazilian states in 2010. An Bras Dermatol. 2016;91(1):28-33. 